Trakya Eğitim Dergisi

Cilt 9, Sayı 3

Eylül 2019, 456-476

Geliş Tarihi: 01.09.2018

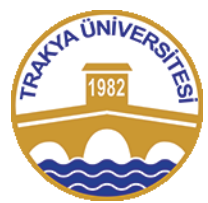

ISSN: 2630-6301
Trakya Journal of Education

Volume 9, Issue 3

September 2019, 456-476

\title{
Ortaokul Türkçe Derslerinde Dinleme Becerisinin Gelişimine Yönelik Öğretmen Uygulamaları
}

\section{Teachers' Applications Aimed At Developing Listening Skill in the Secondary School Turkish Lessons}

\section{Ali GÖÇER ${ }^{1}$, Ceyda ÇAYLI ${ }^{2}$}

\begin{abstract}
Öz: Türkçe Dersi Öğretim Programında yer alan temel dil becerilerinden biri de dinleme becerisidir. Programda, bu becerinin ögrencilere kazandırılması amaçlanmaktadır. $\mathrm{Bu}$ amaç doğrultusunda, öğretmenlerin dinleme becerisinin gelişimine yönelik uygulamaları önemli işlevler görmekte ve büyük önem taşımaktadır. $\mathrm{Bu}$ sebeple araştırmanın temelini öğretmenlerin uygulamaları oluşturmaktadır. Araştırmanın amacı; Milli Eğitim Bakanlığı bünyesinde görev yapan Türkçe öğretmenlerinin, dinleme becerisinin gelişim durumu üzerine uygulamalarıyla ilgili görüşlerini alarak; süreçle ilgili genel görünümü ortaya koymaktır. Araştırmada nitel araştırma yaklaşımı tercih edilmiştir. Araştırmanın çalışma grubu Kayseri merkez ilçelerde görevli öğretmenler arasından rastgele seçilmiştir. Veriler nitel veri toplama yöntemlerinden görüşme tekniği ile elde edilmiştir. Katılımcılara yarı yapılandırılmış görüşme formları uygulanmış, elde edilen veriler kodlanarak temalandırılmış ve yorumlanmıştır.
\end{abstract}

Anahtar sözcükler: Dinleme becerisi, ögretmen uygulamaları, nitel araştırma

\begin{abstract}
Listening skill is one of the main skills which are in the Teaching Programme of Turkish Lesson. In the programme, it is aimed at being acquired this skill by students. In accordance with this objective, teachers' applications aimed at developing listening skill are of crucial importance. For this reason, teachers' applications constitute the foundation of the research.The goal of the research is to demonstrate the overall picture of the learning process by getting the Turkish teachers' opinions relating to their applications regarding the situation of the listening skill development. The qualitative research approach has been prefered in the research. The working group of the research has been chosen randomly among the teachers working in Kayseri. The data has been obtained by means of interview technique which is among methods of qualitative data collection. When interviewing with the participants, semi-structured interview forms have been applied and the collecting data has been grouped thematically by being coded and has been interpreted.
\end{abstract}

Keywords: Listening skill, teacher application, action research

\section{Introduction}

\section{EXTENDED ABSTRACT}

The importance and place of listening skill, which is the first skill being acquired among language skills and may be accepted as a basis of other skills, cannot be denied. The development of an individual's listening skill will also affect that of his other skills. Listening skill and hearing should not be mixed up. Listening requires a conscious process. This process, in which individual willingness is in the forefront, is related to that a person is ready to listen from this perspective, it is appropriate to be stated that the significant difference between hearing and listening is consciousness. Listening skill will improve in the learning process. In the present understanding of education, it is accepted that this skill can be developed. Therefore, teachers playing an important role in enhancing the skill form the basis of the research. It is thought that that teachers' existing applications aimed at developing listening skill are demonstrated contributes to the literature.

\section{Method}

The paradigm of the research is a qualitative case study, which enables the subject to be analysed in detail. The population consists of Turkish lesson teachers who work at the secondary schools in Kayseri. The working group of the research is composed of twenty Turkish teachers who have been chosen randomly. The research data have been collected from semi-structured interview forms and have been evaulated by being analysed their content.

\footnotetext{
${ }^{1}$ Prof. Dr., Erciyes Üniversitesi, Eğitim Fakültesi, Türkçe ve Sosyal Bilimler Eğitimi Bölümü, e-posta: gocer@erciyes.edu.tr, ORCID: 0000- 0002-6880-2611

${ }^{2}$ Türkçe Öğretmeni, Erciyes Üniversitesi, Eğitim Bilimleri Enstitüsü, e-posta: cydcayli@gmail.com, ORCID: 0000-0002-60914811
} 


\section{Results and Discussion}

Considering teachers', participating the research, applications aimed at developing listening skill and the findings concerning their suggestions, that teachers take the view that listening skill can be improved is a acceptable understanding in the existing literature. Teachers' positive attitude towards the development of listening skill will play an important role in an improvement in that skill. In addition to this positive attitude, it is expected that the applications will be a supportive quality in improvement in listening skill However, it is observed in existing practices that teachers perform their duties according to conventional understanding of education.

Considering the data obtained from the answers to the questions asked to learn teachers' applications aimed at developing listening skill, applied before, in the course of and after listening, it is understood that teachers employ some parts of listening strategies. Altough the participant teachers employ some parts of listening strategies in their applications, they do not have knowledge of these strategies. This situation demonsrates the lack of information in the field.

The use of listening strategies plays an essential role in developing listening skill. Therefore, they should be used in the teaching process by teachers.

Teachers make the preparation phases before listening by means of different applications. The main purpose of the preparations is to ensure that students prepare for more active involvement in learning activities through the text in the course of lesson. In accordance with this purpose, teachers should be careful with the preparation applications concerning the listening texts.

That it is not done preparations detrimental to the originality of the listening text and that a student encounters this text in the course of lesson are effective since the student does not lose his interest in the listening text. The constructive education understanding requires to be observed the student's learning process, not to the result of that. It is not sufficient to be solely underpinned this understanding by the conventional measurement and assessment devices.

It is necessary to be employed the suplementary measurement and assessment techniques as well as the conventional ones in being evaluated the process of teaching and learning. In the constructive education understanding, students demonstrate orally their solutions for problems by using different presentation methods or by exhibiting the products which they have improved. Thus teachers require to utilize the suplementary measurement and assessment techniques alongside the conventional ones

The quality of text is important to improve listening skill. Text should be chosen from among ones which rise a student's interest in listening, is appropriate for his demand, especially his level, and have not complicated phrases.

Text is as essential as the approaches for the process of language teaching. As it is known text is the most crucial tool of language teaching. Text is of paramount importance for developing students' language, mental and social skills. Therefore, the selection of text plays a key role in improving listening skill That the text, which is appropriate for students' interest and needs and gives students pleasure, is chosen will contribute to listening skill and affect students' development, their attitude towards listening skill and their achievement in lesson. The methods which contribute to listening skill must be applied. It should be prioritized to use the text which students understand easily and from which they take pleasure listening. In the course of time it is appropriate that the opinion text is employed in parallel with the development of students' abstract thinking skill.

The use of metarial is highly important to listening skill. It is indicated that a person's period of abstract process, suggested by Piaget, begins when he turns 11 . Hence individuals', whose period of abstract process has just began, knowledge should be enhanced by concrete teaching materials The use of teaching metarials helps students to understand a specific subject and to improve their imagination by listening text.

It is known that a physical, psychological and sociological environment plays a crucial role in developing listening skill. Any method applied a person who is not psychologically ready to listen does not succeed. The achievement of a student who has a problem with regard to the social environment is adversely affected. Teachers should observe their students having problems in the classroom and try to solve these problems. The number of students in a classroom draws attention firstly relating to physical environment It is necessary to reduce the class size in order to develop effectively listening skill in classrooms. Furthermore, listening classrooms must be opened for listening text. Regarding classrooms size, that classes size in the listening lessons is limited to 25 students like the provision of the National Education Ministry' regulation concerning the Technology and Desing Lessons, which indicates that "the number of students in the lesson must not exceed 25. The classes where the number of students is more than 25 should be divided into groups", contributes to improve listening skill. 
It is thought by teachers that the acquisition being expected to develop listening skill is not sufficient. The existing educational attainment is expected to contribute to the improvement of listening skill. That teachers' views are taken into consideration concerning the sufficiency of existing educational attainment plays a key role in underpinning the improvement of this skill.The acquisition amounts to experience, knowledge, skill, attitude and values, which is expected a student to obtain in the course of teaching process. Thus it is necessary for teachers to ignore the acquisition in their applications. The acquisition in programme must be taken into consideration by teachers.

The favoured kinds of listening should be diversified as listening text is the subject of a lesson. Each student must be offered a different option due to the fact that each of them has different personality. That a student listens to text which is suitable for his personality will contribute to his achievement in understanding

That students prepare for the lesson before listening will play an important role in listening skill.That students prepare for the listening text, that students' attention is drawn to the subject and that their curiosity is aroused help them understand to what they listen. The importance of the preparation done before listening should not be ignored since it makes students willing to listen. Therefore, it is necessary to be prepared students for the lesson as far as possible before listening.

\section{GİRIŞ}

Dil becerileri içerisinde ilk edinilen ve diğer tüm becerilerin temeli sayılabilecek dinleme becerisinin yeri ve önemi yadsınamaz. Bireyin dinleme becerisinin gelişim durumu diğer becerilerine de etki edecektir. Dinleme ile işitme birbirine karıştırılmamalıdır. Dinleme sürecinde bireyin dinlemeye istekli ve hazır olması gerekmektedir. "Bu açıdan bakıldığında işitme ile dinleme arasındaki belirgin farkın bilinçlilik olduğunun söylenmesi uygun olacaktır (Çaylı \& Göçer, 2016: 518)".

Dinleme ile ilgili çeşitli tanımlar bulunmaktadır. Demirel'e (1999: 33) göre dinleme; konuşan kişinin vermek istediği mesaj1, pürüzsüz olarak anlayabilme ve söz konusu uyarana karş1 tepkide bulunabilme etkinliğidir. Gürel \& Tat'a (2012: 277) göre dinleme; fiziksel, duygusal ve entelektüel girdileri anlam arayışı ile bütünleştiren bir eylemdir. Etkili iletişimin temeli olan dinleme, sözsel iletileri duyma ve duyulanlara anlam kazandırarak tepkide bulunma olarak ifade bulmaktadır. Dinleme, kişinin yalnızca sessel ve sözsüz uyaranları algılaması ile ilgili bir süreç değildir; onları anlaması, anlamlandırması ve tepki vermesiyle tümlenmektedir. Taşer (2012: 206) ise dinlemenin; konuşmada ileri sürülen düşünceleri anlamak, yorumlamak, değerlendirmek, organize etmek, aralarındaki ilişkileri saptamak ve belleğimizde saklamaya değer bulduklarımızı seçip ayırmak olduğunu söylemektedir. Ungan (2009: 136-137) dinleme etkinliği satranç oyununa benzer. Satranç oyunu taşların tek tek hareketi üzerine gelişim gösterse bile, satrançta oyunun bütün yönlerini kontrol etme, taşların geliş yönünden varması muhtemel yönleri tahmin etme ve sonucunun ne olacağını da çözme çabası, dinleme etkinliği için de geçerlidir, der.

Dinleme becerisinin bazı unsurları vardır. Kingen'e (2000) göre, dinleme sürecindeki unsurlar şunlardır (Akt. Doğan, 2007: 5): 1. Algılama: Sesli uyaranları ve sözsüz iletişim sinyallerini fark etme. 2. Dikkati Yoğunlaştırma: Dinlenen şeye odaklanma. 3. Anlamlandırma: Duyulan sesli uyaranı anlama ve yorumlama. 4. Hatırlama (Cevaplama): Tepki verebilmek için sesli uyaranı bellekte saklama.

Dinleme becerisinin türleri ile ilgili olarak literatür incelediğinde yapılan sınıflamalarda farklılıklar olduğu görülmektedir. Hennings (2000) aktif dinleme, stratejik dinleme, diyalog ve sunuya dayalı dinleme, amaçlı dinleme. Amaçlı dinleme de kendi içerisinde bilgi edinici, yorumlayıcı, eleştirel ve estetik dinleme olarak sınıflandırılmıştır (Akt. Akyol, 2012: 4). Millî Eğitim Bakanlığı Türkçe Eğitim Programı dinlemeyi (2006: 62-63); katılımlı dinleme, katılımsız dinleme/izleme, not alarak dinleme/izleme, kendini konuşanın yerine koyarak dinleme/izleme (empati kurma), yaratıcı dinleme/izleme, seçici dinleme/ izleme, eleştirel dinleme /izleme olarak sınıflandırmıştır. Tidyman ve Butterfield (1959: 59) basit dinleme, ayırt edici dinleme, rahatlama için dinleme, bilgi için dinleme, fikirleri düzenleme için dinleme, eleştirel dinleme, yaratıcı dinleme (Akt. Doğan, 2007: 35-36) olarak dinlemeyi sınıflandırmaktadır. Ungan (2009) dinlemeyi; etkili ve etkisiz dinleme ana başlıkları altında sınıflandırmıştır. Etkili dinleme türleri; gönüllü dinleme, stratejik dinleme, amaçlı dinleme, haz almak için dinleme ve eleştirel dinleme. 
Etkisiz dinleme türleri; gönülsüz dinleme, antipatik dinleme, yüzeysel dinleme ve görünüşte dinlemedir.

Dinleme belirli bir süreç içerisinde gerçekleşmektedir. Bu süreç genel olarak; dinleme öncesi, dinleme sıras1 ve dinleme sonrası olarak adlandırılmaktadır. Demirel (1999: 36-37) bu başlıklar altında yapılması gerekenleri şu şekilde sıralamaktadır:

Dinleme öncesi: 1. Tanıtma: Dinlenecek konu hakkında genel bilgi verilir. 2. Kestirme: Konu hakkında öğrencilerin tahminleri alınır. Dinlenecek metnin başlığı söylenerek içerik tahminlerinin sınırı daraltılır. 3. Yeni kelimelerin öğretimi: Dinlenecek metinde geçen yeni kelimeler ve gerekirse yeni cümle kalıpları öğretilir. Yeni öğrenilen kelimeler, bilinen cümle kalıplarıyla yeni öğrenilen cümle yapıları da bilinen kelimelerle verilir. 4. Amaçlı dinleme: Dinleme etkinliğinin amacı belirlenir.

Dinleme sırası: 1. Öğretmen metni yüksek sesle okur. 2. Öğrencilerin, metni dinlerken farklı tonlama ve vurgulara dikkat etmesi sağlanır. 3. Öğrencilerden dinleme sonunda sorulacak sorulara cevap verebilmeleri için gerekli gördükleri yerleri not etmeleri istenir.

Dinleme sonrası: 1. Dinleme metniyle ilgili sorulara cevap verilir. 2. Dinlenen metnin sözlü ya da yazılı özeti çıkarılır. 3. Dinlenen metinle ilgili resimlerin ya da cümlelerin olay sırasına göre dizilmesi istenir. 4. Dinlenen metne uygun başlık önerilir. Dinlemede izlenecek bu sıra, dinleme eğitiminin sistemli bir şekilde gerçekleştirilmesini sağlayacağı gibi öğrencinin kendi dinleme sürecini fark etmesine de yardımcı olacaktır.

Kuşçu (2010: 85-96) dinleme sürecini; dinleme öncesi (ön hazırlık, zihinsel hazırlık, ön bilgileri harekete geçirme, anahtar kelimeler, tahmin, amaç belirleme, tür-yöntem ve teknik belirleme), dinleme aşaması (sözlü anlama, zihinde yapılandırma, bilgiyi uygulama) ve dinleme sonrası şeklinde ifade etmektedir.

Dinleme becerisinin geliştirilebilir bir beceri olduğu (Aytan, 2011; Çaylı, 2012; Epçaçan, 2013; Doğan, 2008; Melanlığlu, 2012; Tabak \& Göçer, 2014) literatürde kabul gören bir anlayıştır. Dinleme, her ne kadar doğuştan getirilen bir yeti olsa da dinleme becerisinin kazanımı bir eğitim sürecini gerekli k1lmaktadır (Maden ve Durukan, 2011: 103). Milli Eğitim Türkçe Öğretim Programı'nda dinleme becerisine yönelik kazanımlara yer verilerek, eğitim öğretim kurumlarında becerinin gelişimi sağlanmaya çalışılmaktadır. Dinleme becerisinin gelişiminde rol oynayan ortaokul öğretmenleri araştırmanın temelini oluşturmaktadır. Dinleme becerisinin gelişimine yönelik olan öğretmen uygulamalarını ortaya koymak bu araştırmanın amacıdır. Araştırma sonucunda elde edilecek bulguların alanyazına katkı sağlayacağı düşünülmektedir.

\section{YÖNTEM}

Araştırmanın modeli, konunun ayrıntılı olarak analiz edilmesine imkân veren nitel bir durum çalışmasıdır. "Nitel durum çalışmasının en temel özelliği bir ya da birkaç durumun derinliğine araştırılmasıdır. Yani bir duruma ilişkin etkenler (ortam, bireyler, olaylar, süreçler vb.) bütüncül bir yaklaşımla araştırılır ve ilgili durumu nasıl etkiledikleri ve ilgili durumdan nasıl etkilendikleri üzerine odaklanılır (Yıldırım \& Şimşek, 2008: 77)".

Araştırmanın evrenini, Kayseri merkez ilçelerde görev yapan ortaokul Türkçe öğretmenleri; çalışma grubunu ise rastlantısal olarak seçilen 20 ortaokul Türkçe öğretmeni oluşturmaktadır. Araştırmadan elde edilen veriler yarı yapılandırılmış görüşme formları ile toplanmıştır. Görüşme formunda yer alan sorular iki farklı uzmanın görüşü alınarak oluşturulmuştur. Ayrıca oluşturulan sorular ön deneme grubu olarak 3 Türkçe öğretmenine uygulanmıştır. Hazırlanan görüşme sorularında öğretmenler tarafından anlaşılmayan ya da yanlış anlaşılan herhangi bir ifade olmadığ 1 görülmüştür. Görüşme sorularından elde edilen veriler içerik analizi yapılarak değerlendirilmiştir. "İçerik analizinde temel amaç, toplanan verileri açıklayabilecek kavramlara ve ilişkilere ulaşmaktır (Yıldırım \& Şimşek, 2008: 227)".

Araştırmada yer alan katılımcılara yönelik kişisel bilgiler "cinsiyet, ortalama sınıf mevcutları, yaş, mesleki yıl” şeklinde tablolaştırılarak sırasıyla aşağıda gösterilmiştir. 
Tablo 1: Cinsiyete Göre Öğretmen Bilgileri

\begin{tabular}{ccc}
\hline Cinsiyet & f & \% \\
Kadın & 13 & 65 \\
Erkek & 7 & 35 \\
Toplam & 20 & 100 \\
\hline
\end{tabular}

Araştırmaya 13 kadın, 7 erkek öğretmen katılmıştır. Katılımcıların \%65’i kadındır. Temel eğitim kurumlarında görev yapan kadın öğretmenler erkek öğretmenlerden fazladır. Araştırmadaki cinsiyet dağılımının, ülke genelindeki genel cinsiyet dağılımına yakın olduğu görülmektedir. "Temel eğitim kademesinde görev yapan öğretmenlerin yüzde 60,8'i kadın, yüzde 39,2'si de erkektir (MEB, 2017)."

Tablo 2: Sınıf Mevcuduna Göre Öğretmen Bilgileri

\begin{tabular}{ccc}
\hline Sinıf Mevcudu & f & \% \\
\hline 24 ve altı & 1 & 5 \\
$25-29$ & 2 & 10 \\
$30-34$ & 13 & 65 \\
35 ve üstü & 4 & 20 \\
Toplam & 20 & 100 \\
\hline
\end{tabular}

Araştırmaya katılan öğretmenlerin sınıf mevcutları ile ilgili bilgiler yukarıdaki tabloda belirtilmektedir. Kayseri merkez ve merkez ilçelerde görev yapan öğretmenlerin \%65'inin sınıf mevcudu 30-34 arasındadır. 30-34 sınıf mevcudu takip eden en yakın değer \%20'i ile 35 ve üstü sınıf mevcutlarıdır. 24 ve altında sınıf mevcudu bulunan öğretmen sayısı ise 1'dir.

Tablo 3: Yaşa Göre Öğretmen Bilgileri

\begin{tabular}{ccc}
\hline Yaş & $\mathbf{f}$ & $\boldsymbol{\%}$ \\
\hline 34 ve altı & 6 & 30 \\
$35-39$ & 5 & 25 \\
$40-44$ & 7 & 35 \\
$45-49$ & 1 & 5 \\
50 ve üstü & 1 & 5 \\
Toplam & 20 & 100 \\
\hline
\end{tabular}

Katılımcı öğretmenlerin yaşlarına yönelik bilgiler tablolaştırıldığında 34-44 yaş arasındaki öğretmenlerin araştırmanın çalışma evreninin \%90'ını oluşturduğu görülmektedir.

Tablo 4: Mesleki Yıla Göre Öğretmen Bilgileri

\begin{tabular}{ccc}
\hline Mesleki Yıl & f & \% \\
\hline $5-9$ & 4 & 20 \\
$10-14$ & 5 & 25 \\
$15-19$ & 8 & 40 \\
$20-24$ & 2 & 10 \\
25 ve üstü & 1 & 5 \\
Toplam & 20 & 100 \\
\hline
\end{tabular}

Mesleki yıla ilişkin bilgiler incelendiğinde, araştırmaya katılan öğretmenlerin \%40’ının 15-19 yıllık mesleki tecrübesinin olduğu görülmektedir. Araştırmaya 5 yılın altında mesleki tecrübesi olan herhangi bir öğretmen katılmamıştır.

\section{BULGULAR}

Bu bölümde araştırmaya katılan öğretmenlerin görüşme formunda yer alan sorulara verdiği yanıtlar araştırmanın amacı doğrultusunda analiz edilerek sunulmaktadır. Araştırmaya katılan öğretmenler araştırma boyunca Ö1, Ö2, ... şeklinde ifade edilmektedir.

Katılımcı öğretmenlerin verdiği cevaplar ayrıntılı şekilde aşağıda verilmektedir. 


\subsection{Dinleme Becerisinin Geliştirilmesine Yönelik Kazanımlar}

Dinleme becerisinin geliştirilmesine etki eden kazanımlara yönelik katılımcı öğretmenlere sorulan sorudan elde edilen veriler aşağıdaki tabloda gösterilmektedir.

Tablo 5: Dinleme Becerisinin Geliştirilmesine Yönelik Kazanımlar

Türkçe öğretim programında yer alan dinleme becerisine yönelik kazanımları nasıl değerlendiriyorsunuz?

\begin{tabular}{|c|c|c|}
\hline Öğretmen & Kod & Tema \\
\hline $\begin{array}{l}\text { Ö2, Ö9, Ö10, Ö12, Ö19: Güzel, uygun } \\
\text { kazanımlar. } \\
\ddot{O} 4, \ddot{O} 7, \quad \ddot{O} 8, \text { Ö14, Ö16, Ö17: Dinleme } \\
\text { becerisine yönelik olan kazanımların yeterli } \\
\text { olduğunu sanmiyorum. } \\
\text { Ö13: Kazanımlar uygun; ama gelistirilebilir. }\end{array}$ & Kazanımların yeterliliği & \\
\hline $\begin{array}{l}\text { Ö3, Ö5: Kazanım ifadeleri çok genel, açık } \\
\text { olarak anlatılmıyor. }\end{array}$ & İfadelerin anlaşılabilirliği & \\
\hline $\begin{array}{l}\text { Ö3: Kazanımlar her sınıf seviyesinde aynı, sınıf } \\
\text { seviyesine göre değişmeli. }\end{array}$ & Sınıf seviyesine uygunluğu & $\begin{array}{l}\text { Kazanımların } \\
\text { Niteliği }\end{array}$ \\
\hline $\begin{array}{l}\text { Ö3: Dinleme becerisine yönelik kazanımlar } \\
\text { okuma metinlerine yönelik olan kazanımların } \\
\text { uyarlanmış hali. }\end{array}$ & Kazanımların özgünlüğü & \\
\hline Ö6: Kazanımları dikkate almıyorum. & Öğretmen faktörü & \\
\hline $\begin{array}{l}\text { Ö15, Ö20: } \quad \text { Kazanımların } \\
\text { uygulanmasılyla ilgili problemler yașanıyor. }\end{array}$ & $\begin{array}{l}\text { Kazanımların } \\
\text { uygulanabilirliği }\end{array}$ & \\
\hline $\begin{array}{l}\text { Ö18: Kazanımlar öğrencilerin günlük } \\
\text { hayatlarına etki etmiyor. }\end{array}$ & $\begin{array}{l}\text { Günlük hayatla } \\
\text { ilişkilendirme }\end{array}$ & \\
\hline
\end{tabular}

Araştırma verilerinden hareketle kazanımlarla ilgili olarak katılımcıların \%55'i olumsuz, $\% 25$ 'i olumlu fikir belirtirken; \%10'u fikir belirtmemiştir. Ayrıca katılımcıların \%5'i hem olumlu hem olumsuz ifadelere yer vermiş, \%5'i ise kazanımları dikkate almadığını ifade etmiştir. Kazanımlarla ilgili “Ö2: Kazanımlar gayet güzel ama ögrenciler bu kazanımların kavramada istekli değiller. Ö9: Kazanımlar gayet uygun ve yeterli sayıda. Ö10: Dinlemeye yönelik kazanımlar ögrencilerin seviyesine uygun. Ö12: Kazanımlar uygun ve olması gereken şekilde seçilmiş. Ö19: Iyi niyetli güzel çalışmalar yapılmış." şeklinde olumlu ifadelerde bulunmuştur. Kazanımlara yönelik olumsuz tutum içerisinde olan öğretmenler; "Ö4: Kazanımların yeterli olduğunu sanmıyorum. Ö7: Pek etkili olduğunu düşünmüyorum. Ö8: Yeterli bulmuyorum. Ö14: Türkçe Dersi Ögretim Programı'nda ve özellikle 8. sinıf kitaplarında yer alan kazanımlar yeterli bulmuyorum. Ö16: Kazanımlarl yeterli bulmuyorum. Ö17: Yetersiz olduklarını düşünüyorum." şeklinde görüş bildirmiştir. Araştırmaya katılan öğretmenlerin kazanımları yetersiz gördüğü anlaşılmaktadır. Ayrıca kazanımların derslerde uygulanabilirliği ile ilgili de olumsuz fikirlerin olduğu görülmektedir. Ö15: Kazanımlar fazla idealist, devlet okullarının çoğunluğunda uygulanabilirliği yok. Ö20: Kazanımlar dinleme becerisini geliştirmeye yönelik; ancak uygulamada sorunlar yaşanıyor.

Dinleme becerisine yönelik olarak Türkçe Öğretim Programı'nda yer alan kazanımların dinleme becerisinin gelişimini desteklemesi beklenmektedir. Ancak katılımcılar kazanımlarla ilgili sorun yaşamaktadır. Ayrıca incelenen gözlem formları arasında yer alan "Ö6: Yazılı kaynaklar fazla etkilemiyor beni, kazanımları dikkate almıyorum." ifadesi önemli görülmektedir. Dinleme becerisine yönelik olarak programdaki kazanımların öğretmenler tarafindan göz ardı edilmemesi gerekir. Kazanımlar; uygulama sonunda öğrencilerin gelişim durumu hakkında öğretmenlere fikir vermesi bakımından önemlidir. 


\subsection{Dinleme Becerisinin Geliștirilmesinde Fiziksel, Sosyal ve Psikolojik Ortam}

Dinleme becerisinin gelişimini desteklemesi bakımından fiziksel, sosyal ve psikolojik ortam ile ilgili olarak öğretmenlerin düşüncelerini öğrenmeyi amaçlayan soruya katılımcıların tümü cevap vermiştir. Verilen cevaplar aşağıdaki tabloda gösterilmiştir.

Tablo 6: Dinleme Becerisinin Geliştirilmesinde Fiziksel, Sosyal ve Psikolojik Ortam

Dinleme becerisinin gelişimini desteklemesi bakımından fiziksel, sosyal ve psikolojik ortamın (sınıf mevcudu, sıra düzeni, öğrenci-öğretmen iletişimi, davranış biçimleri vb.) nasıl nitelikler taşıması gerektiğini düşünüyorsunuz?

\begin{tabular}{lcccc}
\hline \multicolumn{3}{c}{ Öğretmen } & Kod & Tema \\
\hline $\begin{array}{l}\text { Ö1: Seçilen dinleme metinleri ortamdan daha } \\
\text { önemli. }\end{array}$ & $\begin{array}{c}\text { Metin seçiminin } \\
\text { önemi }\end{array}$ & Metin Faktörü \\
& &
\end{tabular}

Ö2, Ö4, Ö5, Ö6, Ö7, Ö8, Ö9, Ö10, Ö11, Ö14, Ö15, Ö16, Ö17, Ö18, Ö19, Ö20: Sinıf mevcudu az olmal1.

Ö3, Ö13, Ö15: Sinıf sessiz olmalı, sınıfta dikkati dağıtacak herhangi bir şey olmamalı.

Ö5, Ö7, Ö14, Ö16, Ö17: Sira düzeni iyi

Fiziksel Ortam ayarlanmalı, öğrenciler rahat oturmalılar. Sınıf ortamı temiz olmalı.

Ö19: Sınıf düzeni öğrencilerin birbirini göreceği şekilde düzenlenmelidir.

Ö3: Sınıftaki ses sistemi düzgün olmalı.

Ö7, Ö16, Ö18, Ö19: Öğretmen-öğrenci ilişkisi

Sinif mevcudu

Sinıf düzeni

güçlü olmalı. Öğretmen ve öğrenciler sorumluluklarını bilmelidir.

Ö15: Öğretmen ses tonuna dikkat etmeli ve beden dilini iyi kullanmalıdır.

Ö2, Ö3, Ö12, Ö13, Ö20: Öğrenciler dinlemeye

Öğrenci faktörü

Psikolojik

Ortam

hazır olmalı ve istekli olmalıdır.

Araştırmaya katılan öğretmenlerin \%80'i sınıf mevcuduna dikkat çekmiştir. Ö2: Sınıf mevcudu öncelikle az olmalıdır. Ö4: Sınıf mevcudu dışındaki maddelerin çok etkili olacă̆ını düşünmüyorum. Ö5: Sinıf mevcudu uygun olmalı. Ö6: Sinıf mevcudu az olmalı. Ö7: Sinıf mevcudunun az olması tabî̀ ki çok etkili. Ö8: Öğrenci sayısının fazla olması dinleme ortamına uygun değildir. Ö9: Sinıf mevcudunun standardın üstünde olmaması lazım. Ö10: Sinıflarımızda sinif mevcudu fazla. Ö11: Sinıf mevcudu az olduğunda daha etkili dinleme yapllyor. Ö14: Dinleme becerisinin gelişimi için sınıf mevcutları daha az olmalı. Ö15: Sinıflar çok kalabalık olmamalı. Ö16: Iyi bir dinleme için sınıf mevcudunun çok fazla olmaması gerekir. Ö17: Çok kalabalık olmayan sınıflar olmalı. Ö18: Sinıf mevcudunun kalabalık olmaması gerekir. Ö19: Sinıf mevcudu 20-25 olmalı. Ö20: Sinıf mevcudunun daha az olmasi gerekir.

Öğretmenlerin \%45'i dinleme becerisine fiziksel ortamın etkileri olduğunu belirtmiştir. Ö3: Dinleme sırasında sınıf sessiz olmall. Ö5: Sıra düzeni önemli. Ö7: Sinıf düzeni, temizliğine dikkat edilmeli. Ö13: Sınıf sessiz olmalı, ögrenci dikkatini verebilmeli. Ö14: Sinıf ortamının ve çevresinin bu becerinin gelişmesine katkı sağlaması gerekmektedir. Ö15: Sinıf sessiz olmall. Ö16: Sira düzeninin uygun olması gerekir. Ö17: Öğrenciler rahat oturduklart sıralarda, dinlemeye hazır hissetmeliler. Ö19: Sınıf düzeni ögrencilerin birbirini göreceği şekilde düzenlenmeli. Katılımc1 öğretmenlerin \%25'i öğrenci faktörünün dinleme becerisinin gelişimde rol oynadığını düşünmektedir. Ö2: Öğrencilerin dinlemeyi ögrenmeleri gerekiyor. Ö3: Öğrencilerin odaklanabilmesi için psikolojileri de önemlidir tabi. Ö12: Öğrencilerin hazırbulunuşluk düzeyinin yerinde olmasl gerekir. Sinıfin dinleme metnine ilgisinin ve isteğinin tam olmasl gerekir. Ö13: Öğrencinin kafası durgun ve sakin olmalı. Ö20: Öğrencinin dinlemeye hazır olmasl gerekiyor. 
Katılımcı öğretmenlerin $\% 25$ 'i dinleme becerisinin gelişimine sosyal ortamın etkileri olduğunu düşünmektedir. Ö7: Öğretmen ve öğrenci ilişkisi çok önemli. Ö15: Beden dili öğretmen tarafindan iyi kullanılmall, ses tonuna dikkat edilmeli. Ö16: Öğretmen ögrenci iletişiminin güçlü olması gerekir. Ö18: Çocukların ögretmenle iletişiminin iyi olması önemlidir. Ö19: Öğretmen ve ögrrenci, her iki tarafta sorumluluklarını iyi bilmeli. Ayrıca "Ö1: Ortamdan çok metin önemli, metinler iyi değilse öğrenme gerçekleşmez. " ifadesinde bulunmuştur. Bu durum öğretmenin; sosyal, psikolojik ve fiziksel ortamdan ziyade metin niteliğine odaklandığını göstermektedir. Seçilen metinlerin niteliği önemlidir; ancak sosyal, psikolojik ve fiziksel ortamın niteliğinin de dinleme becerisinin gelişimine katkı sağladığı göz ardı edilmemelidir.

\subsection{Dinleme Metninin Nitelikleri}

Dinleme metinlerinin taşıması gereken nitelikleri ile ilgili olarak öğretmen görüşlerini almayı amaçlayan sorudan elde edilen veriler aşağıdaki tabloda gösterilmektedir.

Tablo 7: Dinleme Metinlerinin Nitelikleri

Dinleme becerisinin geliştirilmesini desteklemesi bakımından seçilen metinlerin hangi nitelikleri taşıması gerektiğini düşünüyorsunuz?

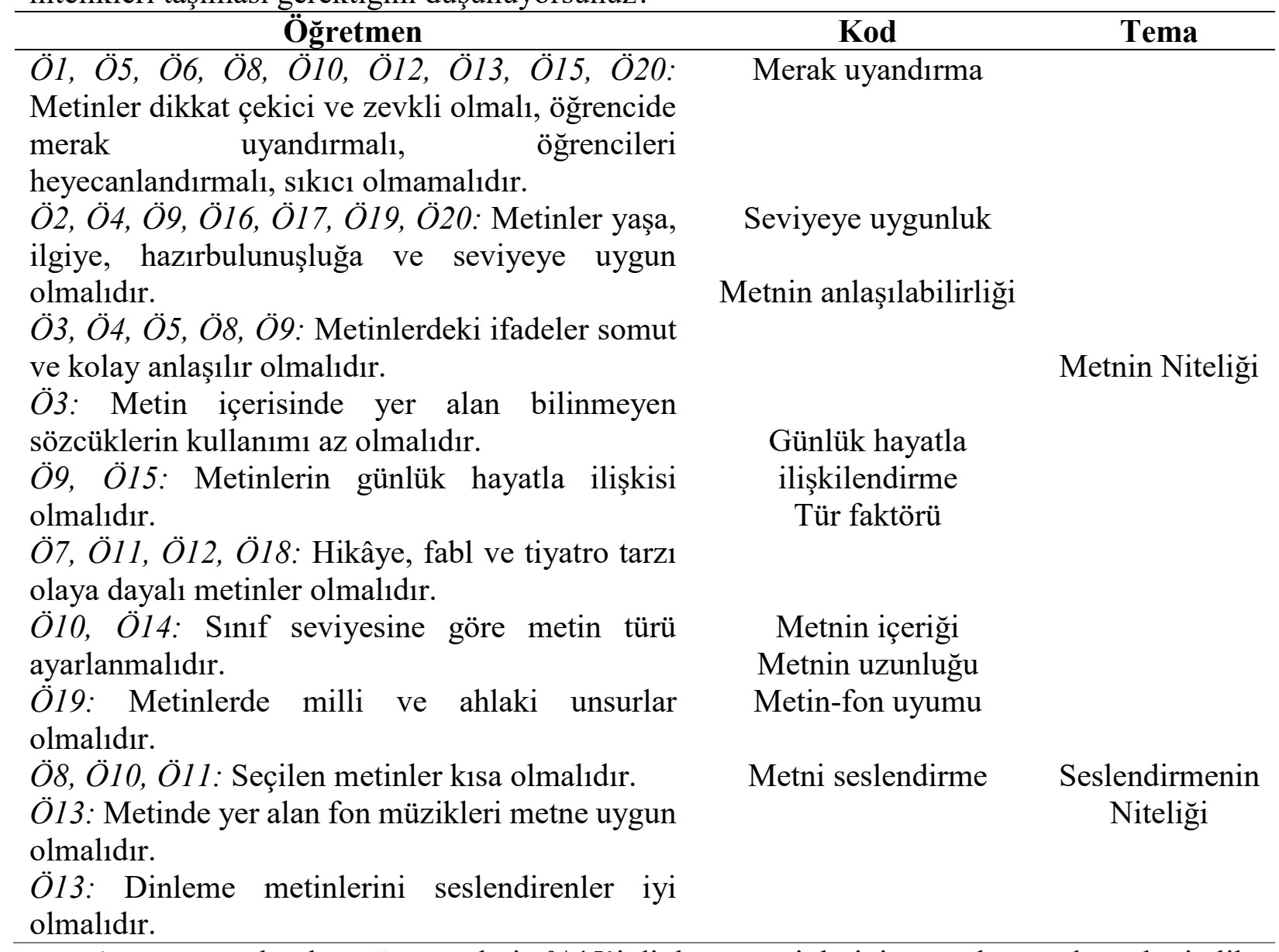

Araştırmaya katılan öğretmenlerin \%45'i dinleme metinlerinin merak uyandıracak nitelikte olması gerektiğini düşünmektedir. Ö1: Merak uyandırmalı. Ö5: Akıcl, kolay anlaşılır ve dikkat çekici olmalıdır. Ö6: Metinler çocukların seviyesine uygun, ilgi çekici, heyecan uyandırıcı nitelikte olmalıdır. Ö8: Dikkat çekici, kisa ve kolay anlaşılır olması gerekir. Ö10: Konuların ilgi çekici olması gerekir. Ö12: İlgi çekici metinler olmalı. Ö13: Daha zevkli anlaşılır metinler olmalı. Ö15: Öğrencilerin ilgilerini çekmeli. Günlük hayatla ilişkilendirilebilmelidir. Ö20: Öğrencide ilgi uyandıracak merak duygusunu ön plana çıkaracak dikkat çekici metinler olmalıdır. Katılımc1 öğretmenlerin \%35'i ise metinlerin seviyeye uygun olması gerektiğini ifade etmektedir. Ö2: Ögrencilerin yaşına ve ilgisine uygun olmalı. Ö4: Yaş ve hazırbulunuşluk seviyesine uygun olmalı. 
Ö9: Yaşa uygun olmall. Ö16: Sinıf seviyesine uygun olmall. Ö17: Çocuğun yaşına uygun olmall. Ö19: Seviyeye uygun olmall. Ö20: Öğrencinin gelişim dönemine uygun olmast gerekir.

Öğretmenlerin \%30'u dinleme metinlerinde metin türüne dikkat edilmesi gerektiğini düşünmektedir. Ö7: Daha çok tiyatro, hikâye tarzı metinler olmalı. Ö11: Çok uzun olmayan, olaya dayalı metinler olmal. Ö12: Metinlerin macera içerikli, komik veya duygusal (masal-hikâye-fabl) olması ögrencilerin metni daha çok sevmesini sağlar. Ö18: Seçilen metnin türü ögrencilerin ihtiyaçlarına uygun olmalıdır. Ayrıca metin türlerinin sınıf seviyesine göre düzenlenmesinin önemine dikkat çeken katılımcılar bulunmaktadır. Ö10: 5-6. Sinıflarda olay yazılarının bol tutulması gerekir. 7-8. sınıflarda kullanılan düşünce yazılarının konuları ilgi çekici olmayınca ve metinler uzun olunca ögrenci sıkllyor. Ö14: 5-6 ve 7. sinıflarda metinlerin olay içerikli metinler olmasl gerekir.

Araştırmaya katılan öğretmenlerin \%25'i seçilen metinlerin kolay anlaşı1lır olmasını istemektedir. Ö3: Cümleler klsa ve anlaşılır olmalı. Metinde bilinmeyen kelime az olmalıdır. Ö4: Metindeki önemli ifadeler kolay ayırt edilebilmelidir. Ö5: Metinler akıcı, kolay anlaşılır ve dikkat çekici olmalıdır. Ö8: Dikkat çekici, kısa ve kolay anlaşılır olması gerekir. Ö9: Metinler kolay anlaşılır olmalı, karmaşa içinde olmamalıdır.

Araştırmada Ö13'ün "Metinde yer alan fon müzikleri metne uygun olmalıdır. Ayrıca dinleme metinlerini seslendirenler iyi olmalıdır." ifadesi dinleme metinlerinde metnin niteliği kadar seslendirmenin de önemli olduğuna dikkat çekmektedir.

Görüşme formlarından elde edilen verilere göre katılımcı öğretmenler dinleme metinlerinin; öğrenci seviyesine uygun, merak uyandıran nitelikte, kolay anlaşılabilir, kısa ve olay yazısı türünde olmasını istemektedir.

\subsection{Dinleme Becerisinin Geliștirilmesine Yönelik Uygulamalar}

Öğretmenlerin dinleme öncesi, dinleme sırası ve dinleme sonrası uygulamalarını öğrenmek amaçlanmaktadır. Bu amaç doğrultusunda sorulan sorular ve sorulara alınan cevaplar sırasıyla aşağıda verilmiştir.

Tablo 8: Dinleme Becerisinin Geliştirilmesine Yönelik Olarak Dinleme Öncesi Öğretmen Uygulamaları

\begin{tabular}{ccc}
\hline Dinleme öncesinde nasıl uygulamalarda bulunuyorsunuz? & \\
\hline Öğretmen & Kod & Tema \\
\hline$\ddot{O} 1, \ddot{O} 2, \ddot{O} 3, \ddot{O} 7, \ddot{O} 8, \ddot{O} 9, \ddot{O} 10, \ddot{O} 11, \ddot{O} / 2, \ddot{O} 14$,
\end{tabular}

Ö1, Ö2, Ö3, Ö7, Ö8, Ö9, Ö10, Ö11, Ö12, Ö14,

Ö16, Ö18, Ö20: Metne dikkat çekmek için ön

hazırlık metinleri okurum, konuşma yaparım, metne yönelik sorular sorarım.

Ö3, Ö4, Ö6, Ö7, Ö13, Ö17: Öğrencileri metni dinlemeye istekli hale getiririm. Dinlenilecek metni öğrencilerin merak etmesini sağlarım. Güdüleyici sorular sorarım.

Ö2, Ö10, Ö13, Ö18: Sessizce beklemelerini isterim, birbirlerini rahatsiz etmeden dinlemeleri gerektiğini hatırlatırım.

Ö5, Ö19: Nasıl dinleme yapacaklarını anlatır, dinleme tekniği ile ilgili bilgiler veririm.

Ö3, Ö15: Öğrencilerin ön bilgilerini yoklarım.

Ö14: Metnin konusunu araştırma konusu olarak önceden veririm.

Araştırmaya katılan öğretmenlerin \%65'inin dinleme öncesinde öğrencilerin dikkatini çekerek derse başlamayı tercih ettiği görülmüştür. Ö1: Öğrencilerin dikkatini çekerek başlıyorum derse. Ö2: Öğrencilerin dikkatini çekmek için konuşma yapıyorum. Ö3: Konuya yönelik dikkat çekme etkinlikleri yapıyorum. Ö7: Öğrencilerin dikkatlerini çekecek bir giriş, bir konuşma 
yapmaya çalışıyorum. Ö8: Öğrencilerin dikkatini çekecek metinler okuyorum. Ö9: Öğrencilerin dikkatini çekecek girişler yaparak ögrencileri derse hazır hale getiririm. Ö10: Konuyla alakalı ilgi çekici şeyler anlatıyorum. Ö11: Öğrencilerin dikkatini toplayacak sorular yöneltiyorum. Ö12: Dinlenilecek metnin önemli bir konu olduğuna vurgu yapıyorum. Ö14: Konunun içeriğine uygun toplumsal olaylardan örnekler bulmaya çalışıyorum. Metinle ilgili sorular soruyorum. Ö16: Ögrencilere konuyla alakalı bilgiler veriyorum. 18: Öğrencilerin dikkatini çekiyorum. 20: Öğrencilerin dikkatini çekerim.

Araştırmaya katılan öğretmenlerin \%30'u dinleme öncesi güdülenmenin önemine dikkat çekmiştir. Ö3: Öğrencilerin başlıktan hareketle kendi hayatlarıyla ilişki kurmalarını să̆llyorum, metni dinlemeye istekli oluyorlar. Ö4: Güdüleyici sorular soruyorum. Ö6: Dinleyecekleri metni günlük hayatla ilişkilendirip dikkatlerini parçaya vermelerini să̆llyorum. Ö7: Metne yönelik güdüleyici çalışmalar yapıyorum. Ö13: Metinle ögrrencilerin günlük hayatlarına yönelik ilişki kurmalarını să̆llyorum, böylece metni dinlemeye istekli hale geliyorlar. Ö17: Öğrencileri metni dinlemeye istekli hale getiriyorum. Araştırmaya katılan öğretmenlerin \%85'inin dinleme öncesi uygulamalarında dikkat çekme ve güdülemeye özen gösterdiği görülmüştür.

Katılımcı öğretmeler dinleme öncesinde, öğrencilerin hazırbulunuşluk durumunu kontrol ettiklerini ifade etmiştir. Ö3: Öğrencilerin konuyla ilgili ön bilgilerini yokluyorum. Ö15: Ögrencilerin ön bilgilerini kontrol ediyorum. Ayrıca katılımcılar arasında dinleme metnini ders öncesinde araştırma konusu olarak veren öğretmen bulunmaktadır. Ö14: Dinleme metnini araştırma konusu olarak veriyorum. Öğretmenlerin dinleme öncesi yaptıkları bir diğger uygulama da dinleme kurallarını hatırlatmaktır. Ö2: Başkalarını rahatsız etmeden dinlemeleri gerektiğini belirtiyorum. Ö10: Sinıfın sessizliğini sağllyorum. Ö13: Hazır sessiz bir şekilde beklemelerini istiyorum. Ö18: Sinıfta sessizliği să̆llyorum.

Dinleme öncesinde katılımcı öğretmenler; öğrencinin dikkatini çekmekte, hazırbulunuşluk durumunu kontrol etmekte, öğrenciyi derse istekli hale getirmekte, uygulanacak dinleme tekniği hakkında bilgi vermekte ve dinleme kurallarına dikkat etmektedir. Dinleme öncesi yapılacak uygulamalar öğrencilerin metne hazırlanmasında önemli rol oynayabilir. Bu sebeple dinleme öncesi hazırlığın öğretmenler tarafından ayrıntı olarak yapılması önemlidir.

Tablo 9: Dinleme Becerisinin Geliştirilmesine Yönelik Olarak Dinleme Sırası Öğretmen Uygulamaları

Dinleme sırasında nasıl uygulamalarda bulunuyorsunuz?

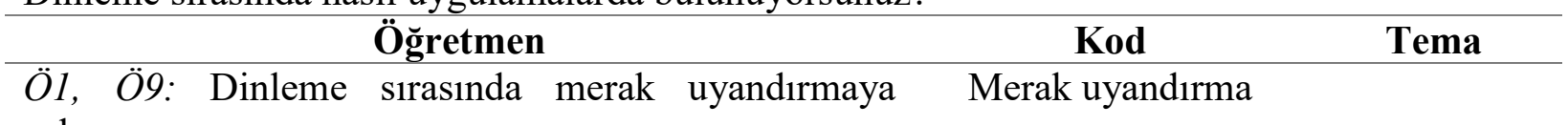

çalışırım.

Ö2, Ö17: Dinleme metninin akışını bozmadan

Katılımsız dinleme

öğrencilerin dinlemelerini sağlarım. Sadece dinleme yaptırırım.

Ö3: Öğrencilerin anlamadığı yerleri açıklayarak dinleme yaptırırım.

Ö5, Ö8, Ö15: Ses tonuna dikkat ederim.

Ö3, Ö6, Ö7, Ö9, Ö10, Ö12, Ö13, Ö15, Ö18, Ö20:

Metnin öncesine, sonrasına ve önemli noktalarına yönelik sorular sorarım.

Ö4, Ö19: Dinleme sırasına önemli noktaları Dikkat çekme

Açıklama yapma

Vurgu ve tonlama

Dinleme

Soru-cevap yöntemi Siras1

Uygulamaları

vurgulayarak dinleme yaparım.

Ö5, Ö9, Ö15: Jest ve mimiklerle, uyarı ve göz

temasıyla dikkat çekmeye çalışırım.

Ö9, Ö16: Dikkat çekici konuşmalar yaparım.

Ö7: Metni dinlerken ögrencilerin örnekler vermesini isterim.

Metni içselleştirme 
Ö7: Öğrencilerin dinlenilen yere kadar metni

özetlemesini isterim.

Ö11: Dinleme sırasında öğrencilere, dinlediklerini Dinleme stilini seçme gözlerinde canlandırmalarını söylerim.

Ö14: Kazanımlara uygun dinleme tekniği ile dinleme gerçekleştiririm.

Araştırmada yer alan öğretmenlerin \%50'si dinleme sırasında öğrencilere soru sorduğunu ifade etmiştir. Ö3: Öyküleyici metinlerde metni durdurup sorular sorarım. Metnin devamını tahmin etme çalışmaları yaparım. Bunun çok etkili olduğunu gördüm. Uzun bir düşünce yazısı dinliyorsak metni arada bir durdurarak açıklamalar yaparım. Bu sayede ögrencilerin dikkatini toplamasl ve metne odaklanması kolay oluyor. Ö6: Belirli yerlerde durup metnin öncesi ve sonrasıla ilgili sorular soruyorum. Ö7: Metnin başında konuyla alakalı soru sorarım, ortasında dikkatlerini toplayacak örnek verme, soru sorma gibi uygulamalarda bulunurum, en sonunda ise metnin özetlenmesini isterim. Ö9: Konuyla ilgili sorular sorarım. Ö10: durarak soru soruyorum. Ö12: Metni bölüp önemli noktalarda sorular sorarak ders işliyorum. Ö13: Dinlerken birden metni durdurup "Metinde acaba neler olmuştur?" gibi tahmin sorularl soruyorum. Ö15: Dinleme metnine ara verip kisa sorular soruyorum. Ses tonuma ve vücut dilime dikkat ediyorum. Ö18: Dinleme sürecini yarıda kesip metnin devamın tahmin etmelerini istiyorum. Ö20: Metnin bazı noktalarında durarak ögrencilere dinledikleri yerlerle ilgili sorular yöneltiyorum ve metnin devamında neler olacă̆ ile ilgili tahminlerde bulunmalarını istiyorum.

Katılımc1 öğretmenlerin \%35'i dinleme sırasında öğrencilerin dikkatini çekmeye yönelik uygulamalarda bulunmaktadır. Ö4: Dinleme esnasında dikkat çekici ifadeleri vurgulamak için uyarılarda bulunuyorum. Ö5: Gerek ses tonu, gerekse mimiklerle dikkat çekerek ilgiyi topluyorum. Ö9: Ögrencileri kontrol eder, uyarır, göz temasında bulunurum. Dinleme metnine ilgi azaldiysa dikkatlerini toplayacak konuşmalar, hareketler yaparım. Ö15: Ses tonuma ve vücut dilime dikkat ederek dikkatlerini canlı tutmaya çalışırım. Ö16: Dinledikleri konudan sıkılmamaları için ilgilerini çeken konulardan bahsediyorum. Ö19: Bazen önemli gördüğ̈̈m yerlerde durdurup dikkat etmeleri gereken noktalarl vurguluyorum.

Dinleme metninin seslendirilmesi ile ilgili olarak katılımcıların \%15'i görüş bildirmiştir. Ö5: Gerek ses tonu, gerekse mimiklerle dikkat çekerek ilgiyi topluyorum. Ö8: Ses tonunun ortama uygun olmasina dikkat ediyorum. Ö15: Ses tonuma ve vücut dilime dikkat ediyorum.

Dinleme esnasında herhangi bir uygulamada bulunmadığını belirten öğretmenlerin olduğu “Ö2: Konuyu akışı bozmadan dinlemelerini sağllyorum. Ö17: Sadece dinliyorlar.” ifadelerinden anlaşılmaktadır.

Katılımcı öğretmenler, dinleme sırasında; öğrencinin dikkatini metne ve konuya çekerek merak uyandırmakta, dinleme metninin seslendirmesine dikkat etmekte, soru-cevap yöntemi ile öğrencileri sürece dâhil etmeye çalışmakta ve öğrencilerin metni içselleştirmesine imkân verecek uygulamalarda bulunmaktadır.

Tablo 10: Dinleme Becerisinin Geliştirilmesine Yönelik Olarak Dinleme Sonrası Öğretmen Uygulamaları

Dinleme sonrasında, öğrencilerin dinlediğini anlama başarılarını değerlendirirken nasıl uygulamalarda bulunuyorsunuz?

\section{Öğretmen}

Ö1, Ö4, Ö5, Ö7, Ö8, Ö9, Ö10, Ö12, Ö14, Ö15, Ö16,

Ö17, Ö19, Ö20: Metne yönelik sorular sorarım.

Ö6, Ö17: Öğrencilerin soru hazırlamalarını isterim.

Ö3: Sözcük çalışmasında bulunarak, öğrencilerin yeni sözcük öğrenmesini sağlarım.

Ö2, Ö3, Ö13: Çalışma kitabında yer alan etkinlikleri yaparım.
Kod

Tema

Soru-cevap yöntemi

$\begin{array}{cc}\text { Sözcük öğretimi } & \begin{array}{c}\text { Dinleme } \\ \text { Sonrası } \\ \text { Uygulamaları }\end{array} \\ \begin{array}{c}\text { Etkinlikleri } \\ \text { cevaplama }\end{array} & \end{array}$


Ö6, Ö11, Ö15, Ö18, Ö19: Dinlenilenleri öğrencilere Metni içselleştirme

anlattırırım, konunun özetini yaptırırım.

Ö12: Metni devam ettirme çalışması yaparım.

Ö18: Öğrencilerin metne uygun başlık bulmalarını isterim.

Ö19: Öğrencilerin metni eleştirmelerine imkân veririm,

Eleştirel bakış açısı

metinde doğru ya da yanlış buldukları yerleri sorarım.

Dinleme sonrası yapılan uygulamalara yönelik olarak öğretmenlerin yanıtları incelendiğinde, katılımcıların \%70'inin soru sormayı tercih ettiği görülmüştür. Soru sormayı tercih eden öğretmenlerin \%28,6's1 öğrencilere soru sormanın yanı sira farklı uygulamalarda bulunduğunu ifade etmiştir. Araştırmaya katılan öğretmenlerin \%35'i dinleme sonrasında dinlediğini anlama becerisinin durumunu değerlendirmek için birden fazla uygulamayı tercih etmektedir. Öğretmenlerin \%65'i öğrencilerin dinlediklerini anlama durumunu değerlendirirken uygulamalarını çeşitlendirmemektedir. Elde edilen verilerden hareketle, öğretmenlerin geleneksel ölçme değerlendirme uygulamalarıyla sınırlı kaldıkları görülmektedir.

\subsection{Dinleme Becerisinin Geliştirilmesine Yönelik Öğretmen Uygulamalarında Dinleme Stratejilerinin Kullanım Durumu}

Dinleme stratejilerinin kullanım durumunu öğrenmek için katılımcı öğretmenlere "Dinleme stratejileri hakkında bilgi sahibi misiniz? Cevabınız evetse," ş̧eklinde soru sorulmuştur. Araştırmaya katılan öğretmenlerin \% 65'i konu hakkında bilgi sahibi olmadığını belirtmiştir.

Konu hakkında bilgi sahibi olduğunu ifade eden katılımcılara iki soru sorulmuştur. İlk soruda öğretmenlerin stratejileri kullanma durumu, ikinci soruda tercih ettiği stratejiler öğrenilmek istenmiştir. Görüşme formlarında strateji kullandığını ifade eden; ancak tercih ettiği stratejiler hakkında bilgi vermeyen öğretmenler olmuştur.

Araştırmaya katılan öğretmenlerin dinleme stratejilerini kullanım durumuna yönelik olarak sorulan sorudan elde edilen veriler tabloda gösterilmektedir.

Tablo 11: Dinleme Becerisinin Geliştirilmesine Yönelik Öğretmen Uygulamalarında Dinleme Stratejilerinin Kullanım Durumu

Dinleme stratejilerini etkili olarak kullanıyor musunuz?

\begin{tabular}{|c|c|c|}
\hline Öğretmen & Kod & Tema \\
\hline $\begin{array}{l}\ddot{O} 1, \ddot{O} 4, \ddot{O} 11, \quad \ddot{O} 12, \ddot{O} 13: \text { Dinleme stratejilerini } \\
\text { uygulamalarımda kullanmaya çalışırım. }\end{array}$ & Strateji & $\begin{array}{l}\text { Dinleme } \\
\text { Stratejileri }\end{array}$ \\
\hline
\end{tabular}

Ö15, Ö18: Evet, dinleme stratejilerini kullanırım.

Araştırmaya katılan öğretmenlerin \%35'i dinleme stratejileri hakkında bilgi sahibi olduğunu ve dinleme stratejilerini derslerinde kullanmaya çalıştığını ifade ederken; \%10'u ise derslerinde dinleme stratejilerini kullandığını ifade etmektedir.

Derslerinde dinleme stratejilerini kullanma durumuna "evet" diyerek kesin cevap veren Ö15 ve Ö18'den Ö15'in dinleme stratejilerinin kullanımına yönelik olan diğer soruya cevap vermediği görülmüştür. Ayrıca dinleme stratejilerini uygulamalarında kullanmaya çalıştığını ifade eden Ö1, Ö4, Ö11 ve Ö12 de diğer soruya cevap vermemiştir.

Tablo 12: Dinleme Becerisinin Geliştirilmesine Yönelik Öğretmen Uygulamalarında Kullanılan Dinleme Stratejileri

Sınıf içerisinde en çok hangi dinleme stratejilerini tercih ediyorsunuz?

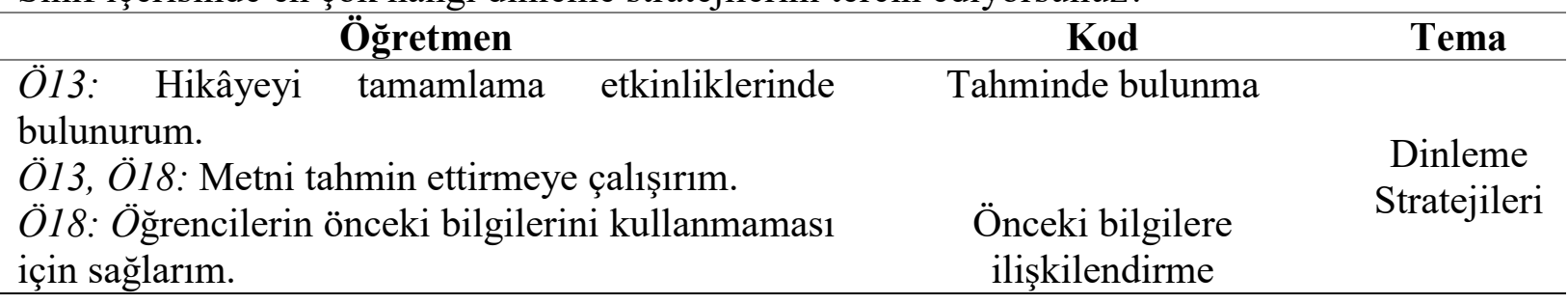


Ö18: Anahtar kelimeleri kullanarak öğrencilerin Anahtar kelimelerle çalışma metni anlamalarına yardımcı olurum.
Ö18: Öğrencilerin dinledikleri metni sözlü olarak
Özetleme

özetlemelerini isterim.

Katılımcı öğretmenlerin \%15’i soruya cevap vermiştir. Alınan cevaplar incelendiğinde öğretmenlerden birinin verdiği cevapların dinleme stratejileri ile ilgisinin olmadığı görülmüştür. Ö11: Derslerimde bilgilendirici dinlemelerde bulunurum. Bu sebeple sadece konu ile ilgili olarak verilen cevaplar dikkate alınmıştır.

Dinleme stratejilerine yönelik katılımcılardan ikisinin soruya yönelik cevap vermiştir. Ö13: Metni tahmin ettiririm. Hikâyeyi tamamlama etkinliklerinde bulunurum. Ö18: Metni tahmin çalışmalarında bulunurum. Öğrencilerin önceki bilgilerini kullanmalarını sağlamaya çalışırım. Anahtar kelimelerden faydalanırım. Dinledikleri metni sözlü olarak özetlemelerini isterim.

Dinleme stratejilerine yönelik olarak öğretmenlere sorulan sorulardan elde edilen verilerden hareketle, katılımcı öğretmenlerin dinleme stratejileri hakkında yeterli bilgiye sahip olmadığ görülmüştür. Öğretmenlerin uygulamalarında; dinleme öncesi, dinleme sırası ve dinleme sonrası stratejilerine yer vermesi dinleme becerisinin gelişimi açısından önemlidir.

\subsection{Dinleme Becerisinin Geliştirilmesine Yönelik Öğretmen Uygulamalarında Dinleme Türlerini Kullanım Durumu}

Dinleme türlerinin kullanım durumunu öğrenmek amacıyla katılımcı öğretmenlere "Dinleme türleri hakkında bilgi sahibi misiniz? Cevabınız evetse," şeklinde soru sorulmuştur. Araştırmaya katılan öğretmenlerin \%20'si konu hakkında bilgi sahibi olmadığını belirtmiştir. Konu hakkında bilgi sahibi olduğunu ifade eden katılımcılara diğer soruda; dinleme türlerini derslerde çeşitlendirme durumları ve tercih ettikleri dinleme türleri sorulmuştur.

Öğretmen uygulamalarında dinleme türlerinin kullanım durumunu öğrenmeyi amaçlayan sorulara verilen yanıtlar aşağıda verilmiştir.

Tablo 13: Dinleme Becerisinin Geliştirilmesine Yönelik Öğretmen Uygulamalarında Farklı Dinleme Türlerinin Kullanım Durumu

Dinleme türlerini çeşitlendirerek etkili olarak kullanıyor musunuz, genel olarak derslerinizde her zaman aynı dinleme türünü mü tercih ediyorsunuz?

\begin{tabular}{lllllll}
\hline \multicolumn{9}{c}{ Öğretmen } & Kod & Tema \\
\hline$\ddot{O} 1, \quad \ddot{O} 2, \quad \ddot{O} 3, \quad \ddot{O} 17, \quad \ddot{O} 19: \quad$ Hayır, genelde & &
\end{tabular}

uygulamalarımda aynı dinleme türünü tercih ediyorum.

Ö4, Ö6, Ö10, Ö14: Evet, farklı dileme türlerini kullanmayı tercih ederim.

Ö9, Ö11: Sikl1kla dinleme türlerini çeşitlendirerek kullanmaya çalışırım.

Ö15, Ö18, Ö20: Bazen dinleme türlerini farklı kullanmayı tercih ederim.

Yukarıda verilen tablo incelendiğinde; dinleme türlerini çeşitlendirerek kullandığını ifade eden $\% 45$, dinleme türlerini çeşitlendirerek kullanmayan $\% 25$, konu hakkında bilgi sahibi olmayan ya da bilgisi olduğunu ifade etmesine rağmen soruya ilişkin cevap vermeyen \%30 katılımcı ögretmen olduğu görülmektedir.

Farklı dinleme türlerinin kullanım durumunu öğrenmeyi amaçlayan soruya "Ö12: Plan dışında etkinlik yaptırmadım. Ö13: Müfredattaki metinleri dinletiyorum. Ö15: Beyin firtınası yapıyorum." şeklinde verilen cevapların konu ile ilgisinin olmadığı görülmüş̧ür. Katılımc1 öğretmenler Ö12 ve Ö13 dinleme türlerine yönelik olan diğer soruya da konu ile ilgisiz yanıt vermiştir. Konu hakkında bilgi sahibi olduğunu ifade etmesine rağmen, katılımcıların dinleme türleri hakkında bilgi sahibi olmadığı anlaşılmıştır. Bu durum sonucunda dinleme türleri hakkında bilgi sahibi olan öğretmen oranı \% 70'e düşmüştür. 
Tablo 14: Dinleme Becerisinin Geliştirilmesine Yönelik Öğretmen Uygulamalarında Kullanılan Dinleme Türleri

Sınıf içerisinde en çok hangi dinleme türlerini tercih ediyorsunuz?

\section{Öğretmen}

Kod

Tema

Ö2, Ö3, Ö4, Ö10, Ö11: Uygulamalarımda genellikle Kat1lımsız dinleme katılımsız dinlemeyi kullanırım.

Ö6, Ö9, Ö10, ̈̈11, Ö15, Ö18: Uygulamalarımda Katılımlı dinleme kat1lımlı dinlemeyi tercih ederim.

Ö6, Ö9: Derslerimde yaratıcı dinlemeyi tercih ederim. Yaratıcı dinleme

Ö11, Ö14, Ö15: Genellikle eleştirel dinlemeyi Eleştirel dinleme

Dinleme

Türleri

kullanırım.

Ö14, Ö17, Ö18, Ö19, Ö20: Derslerimde en çok not alarak Not alarak dinleme dinlemeyi kullanırım.

Araştırmaya katılarak cevap veren öğretmenlerin \%30'u katılımlı, \%25'i not alarak, \%25'i katılımsız, \%15'i eleştirel dinlemeyi uygulamalarında tercih ettiğini belirtmiştir.

Sınıf içerisinde öğretmenler tarafindan tercih edilen dinleme türlerinin öğrenilmesine yönelik hazırlanan soruya "Ö12: Metinleri dinletiyorum. Ö13: Kafama göre metin seçmiyorum. Planda ne varsa onu işliyorum yoksa yetişmiyor." şeklinde yanıt vermiştir. Katılımcı öğretmenlerin yanıtlarının konu ile ilgisinin olmadığı görülmüştür.

\subsection{Dinleme Becerisinin Geliştirilmesine Yönelik Öğretmen Uygulamalarında Yardımcı Materyallerin Kullanım Durumu}

Dinleme becerisinin geliştirilmesine yönelik öğretmen uygulamalarında yardımcı materyallerin kullanım durumunu öğrenmek amacıyla sorulan soruya alınan cevaplar aşağıdaki tabloda verilmektedir.

Tablo 15: Dinleme Becerisinin Geliştirilmesine Yönelik Öğretmen Uygulamalarında Yardımcı Materyallerin Kullanım Durumu

Dinleme becerisinin gelişimi için dinleme uygulamalarında yardımcı materyal kullanıyor musunuz, kullaniyorsanız hangilerini tercih ediyorsunuz?

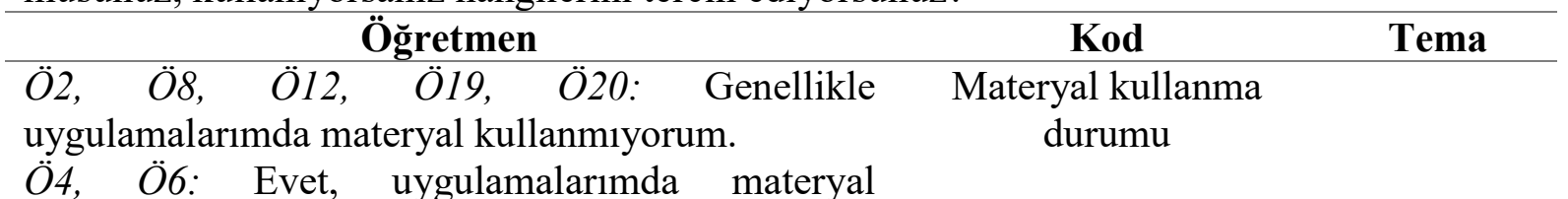

kullanımına özen gösteririm.

Ö17: Özellikle materyal kullanımını tercih etmiyorum.

Ö18: Ders kitaplarını kullanırım, etkinlikleri yaptırırım.

$\ddot{O} 1, \quad \ddot{O} 9, \quad \ddot{O} 10, \quad \ddot{O} 11, \quad \ddot{O} 16:$ Uygulamalarimda materyal olarak akıllı tahtayı kullanırım.

Yazilı materyal

kullanma

Görsel/işitsel materyal kullanma

Ö3, Ö16: Dinleme metnini telefondan öğrencilerime dinletirim.

Ö5, Ö7, Ö13, Ö15: Görseller kullanırım. Drama yaparım, resim gösteririm.

Ö14: Dinleme sırasında fon müziği kullanırım.

Araştırmadan elde edilen verilere göre, katılımcı öğretmenlerin \%30'unun uygulamalarında yardımcı materyal kullanmadığı görülmüştür. Yardımcı materyal kullanımını tercih etmeyen $O ̈ 17$ "Özellikle tercih etmiyorum. Bazı materyallerin öğrencilerin yaratıcılı̆̆ını engellediğini düşünüyorum." demiştir. Öğrencilerin dinleme metinlerinde yardımcı materyal kullanımına ihtiyaç duyduğu göz ardı edilmemelidir. Bu sebeple derslerde yardımcı materyal kullanımına özen gösterilmelidir. 
Araştırmaya katılan öğretmenlerin \%20'si dinleme becerisinin gelişiminde görsel içerikli materyal kullanımına dikkat çekmiştir. Ö5: Görsel materyalleri kullanarak daha kalıcı sonuçlar elde edebiliriz. Ö7: Görsel materyaller kullanmay tercih ederim. Ö13: Metinle ilgili varsa resimler gösteriyorum. Metni görsellerle desteklemeye çalışıorum. Ö15: Konuyla ilgili görsellerden yararlanıyorum. Materyal olarak görsel unsurların tercih edilmesi öğrencilerin dinlediklerini anlamalarına yardımcı olacaktır. Görsel unsurların yanı sıra işitsel materyallere uygulamalarında yer veren Ö14 “Dinleme sırasında fon müziği kullanırım.” demiştir.

Yardımcı materyal kullanımı ile ilgili olarak görüşme formlarından elde edilen verilere göre; öğretmenlerin metni telefondan ya da akıllı tahtadan dinletmeyi tercih ettiği anlaşılmıştır. Ayrıca öğretmenlerin derslerinde görsel ögeleri, fon müziğini, drama gibi uygulamaları da kullanarak dinleme becerisinin gelişimini desteklediği fark edilmiştir.

Öğretmen kılavuz kitaplarının kaldırılmasından sonra öğretmenlerin dinleme metinlerini sınıfta okumaları/okutmaları ön hazırlık olmaksızın mümkün değildir. Bu sebeple dinleme metninin öğrencilere dinletilmesinde aracı olan akıllı tahta ve telefon gibi materyaller zorunlu olarak ders uygulamalarında yer almaktadır. Bu iki materyalin kullanımı dinleme metinleri için ders kitabı niteliğinde bir işlevselliktedir. Bu nedenle okulun ve sınıfın teknolojik imkânlarının yeterliliği önemlidir.

\subsection{Dinleme Becerisinin Geliştirilmesine Yönelik Uygulamalara Öğretmen Önerileri}

Katılımcı öğretmenlerin dinleme becerisinin gelişimine yönelik uygulamalar hakkındaki önerileri aşağıda tablolaştırılmıştır.

Tablo 16: Dinleme Becerisinin Geliştirilmesine Yönelik Uygulamalara Öğretmen Önerileri Dinleme becerisinin nasıl uygulamalarla geliştirilebileceğini düşünüyorsunuz?

\section{Öğretmen}

Ö1, Ö13, Ö16: Öğrencilerin dinlerken sık1lmalarını engelleyecek, zevkli ve merak uyandıracak metinler seçilmelidir.

Ö1, Ö3, Ö6, Ö12, Ö16, Ö19: Öğrencilerin ilgi ve seviyesine uygun metinler seçilmelidir.

Ö13: Metnin süresi uzun olmamalıdır.

Ö2: Daha çok etkinlik yapılmalıdır.

Ö8: Konunun üzerinde bol örneklerle durulmalıdır.

Ö9: Konuyla ilgili merak uyandırıcı konuşmalar yapilmalıdır.

Ö9: Soru-cevap ve tartışma ile dikkat canlı tutulmalıdır.

Ö9, Ö15: Günlük hayatla ilişkilendirerek örnek vermelidir.

Ö15: Konuyla ilgili fikra ve mizah unsurları kullanılmalıdır.

Ö17:Metinde yer alan anlamı bilinmeyen kelimelerin anlamları metnin bağlamından tahmin ettirilmelidir.

Ö18: Anahtar kelimeler belirlenmelidir.

Ö17: Dinleme sayısı artırılmalıdır.

Ö9, Ö17: Sınıfın sessizliği sağlanmalıdır.

Ö11: Dikkat dağıtacak unsurların önüne geçilmelidir.

Ö10: Dinleyici ile konuşmacının iletişim halinde olması gerekir.

Ö4: Dinleme becerisi not alarak dinleme yapılırsa daha iyi gelişebilir.

Ö5: Dinleme becerisi dinlenilenlere öğrencilerin dikkat vermesiyle gelişir.

Ö20: Dinleme becerisi öğrencinin hazırbulunuşluğu yeterliyse gelişebilir.
Kod

Metin niteliği

Tema

Ders içi

uygulamaları

Dinleme

Becerisinin

Gelişimi

Dinleme sayıs1

Ortamın niteliği

Dinleme türü

Öğrenci faktörü 
$\begin{aligned} & \text { Ö7, Ö14, Ö15: Görsel sunu, video ve müzik desteği } \\ & \text { olmalıdır. }\end{aligned}$

Katılımcı öğretmenlerin, dinleme becerisinin gelişimine yönelik yapılabilecek uygulamalarla ilgili önerilerde bulunması istenmiştir. Katılımcıların \%35'i dinleme becerisinin gelişiminde metin seçiminin önemi üzerinde durmaktadır. Ö1: Dinleme metinlerinin en büyük sıkıntısı çocukların ilgi ve seviyelerine uygun olmaması ve çocuklarda merak duygusu oluşturmamasıdır. Ö3: Dinlenilen metin ilgi çekici olduğu sürece problem yok. İlgi çekici metinler kullanarak dinleme becerisi geliştirilebilir. Ö6: Çocukların ilgi ve dikkatlerinin dă̆lmayacağ konularda metinlerin seçilmesi gerekir. Ö12: İlgi çekici metin ve anlatımlarla dinleme becerisi gelişebilir. Ö13: Seçilen dinleme metni zevki olmalı ve uzun olmamalıdır. Ö16: Çocukların ilgisini çekebilecek konular seçilmelidir. Ö19: Ilgi ve seviyeye uygun metin seçimiyle dinleme becerisi geliştirilebilir. Katılımcı öğretmenlerin \%25'i ders içi uygulamalarının dinleme becerisinin gelişimine katk1 sağlayacağını belirtmiştir. Ö2: Daha çok etkinlik yapılmalıdır. Ö8: Bol örnek verilmelidir. Ö9: Konuyla ilgili merak uyandırıcı konuşmalar yapılmall, sınıfta ortamın sessizliği să̆lanmalı, soru-cevap teknikleri kullanılmalı ve tartışma ortamı oluşturularak öğrencilerin dikkati canlı tutulmalıdır. Ö15: Konuyla ilgili kısa fikra ya da mizah unsurları kullanılmalıdır. Metin günlük hayatla ilişkilendirilmelidir. Ö17: Öğrencilere anlamını bilmediği kelimeler, metninin akışından tahmin ettirilmelidir. Ö18: Metinin anahtar kelimeleri belirlenebilir.

Araştırmaya katılan öğretmenlerin \%15'i görsel materyal kullanımına dikkat çekmiştir. Ö7: Metin görsellerle, örneklerle, dramalar ile desteklenirse dinlenilir, ögrenilir. Ö14: Dinleme becerisini görsel sunular, videolar ya da müzikler (fon müzikleri) ile zenginleştirerek geliştiririz. Ö15: Metinler görsellerle desteklenmelidir. Bununla birlikte sınıf ortamının dinleme becerisine etki ettiğine dikkat çeken katılımcı öğretmenler olduğu görülmüştür. Ö9: Sınıfta ortamın sessizliği sağlanmalı, soru-cevap teknikleri kullanılmalı ve tartışma ortamı oluşturularak ögrencilerin dikkati canlı tutulmalıdır. Ö11: Öğrencilerdeki dikkat dă̆ınıklı̆̆ının önüne geçilirse dinleme becerisi geliştirilebilir. Ö17: Ortam sessiz olmalıdır.

Dinleme becerisinin gelişimine yönelik olarak öğretmenlerin önerileri; metin niteliği, öğretmenlerin ders içi uygulamaları, öğrenci faktörü, ortamın sosyal boyutu, dinleme sayısı ve materyal kullanımı üzerinedir. Öğretmenler özellikle metnin niteliğine dikkat çekmiş, metin niteliğinin dinleme becerisinin gelişimine etki edeceğini ifade etmiştir.

\subsection{Dinleme Becerisinin Geliştirilebilirliğine Yönelik Öğretmen Görüşleri}

Araştırmada yer alan ilk soru öğretmenlerin dinleme becerisine bakış açısını öğrenmek amacıyla sorulmuştur. Sorulara verilen cevaplar aşağıdaki tabloda verilmektedir.

Tablo 17: Dinleme Becerisinin Geliştirilebilirliğine Yönelik Öğretmen Görüşleri

Dinleme becerisinin geliştirilebilir bir beceri olduğunu düşünüyor musunuz?

\begin{tabular}{lcc}
\hline \multicolumn{1}{c}{ Öğretmen } & Kod & Tema \\
\hline$\ddot{O} 2, \ddot{O} 3, \ddot{O} 4, \ddot{O} 5, \ddot{O} 6, \ddot{O} 7, \ddot{O} 8, \ddot{O} 9, \ddot{O} 10, \ddot{O} 11, \ddot{O} 12$, & $\begin{array}{c}\text { Dinleme } \\
\text { becerisini }\end{array}$ & $\begin{array}{c}\text { Dinleme } \\
\text { Becerisinin } \\
\text { geliştirilebilir. }\end{array}$ \\
$\ddot{O} 1$ : K1smen. & geliştirme & Geliştirilebilirliği
\end{tabular}

Araştırmada yer alan katılımcıların \%95'i dinleme becerisinin geliştirilebilir bir beceri olduğunu düşünmektedir. Ancak görüşme formları arasında yer alan "Ö1: Kısmen" yanıtı; katılımcı öğretmenin dinleme becerisinin geliştirilebileceği ile ilgili karasızlık içerisinde olduğunu düşündürmüştür. Dinleme becerisinin geliştirilebilir olduğu görüşünün öğretmenler tarafından kabul görmesi, bu becerinin gelişimine katkı sağlayabilir.

\section{TARTISYMA VE SONUC}

Milli Eğitim Bakanlığı tarafından Türkçe Dersi Öğretim Programı'nda yer alan kazanımlarla dinleme becerisi geliştirilmeye çalışılmaktadır. Ancak araştırma sonucunda; dinleme becerisinin gelişimine rehber olması beklenen kazanımların, öğretmenler tarafından yeterli görülmediği 
anlaşılmaktadır. Akademisyenlerin ve öğretmenlerin görüşleri dikkate alınarak kazanımlarda düzenlemelerde bulunulması dinleme becerisinin gelişimine katkı sağlayabilir. Kazanımlar "Öğretim süreci içerisinde planlanmış yaşantılarla öğrencide görülmesi beklenen bilgi, beceri, tutum ve değerlerdir (MEB, 2006: 11)." Bu sebeple kazanımların önemi göz ardı edilmemelidir. Ayrıca, uygulamalarında kazanımları dikkate almadığını belirten öğretmenlerin var olduğu araştırmada ortaya çıkmıştır. Öğretmenlerin uygulamalarında kazanımları göz ardı etmemesi dinleme becerisinin gelişimi açısından etkili olacaktır.

Öğrencilerin fiziksel, psikolojik ve sosyal ortamdan kaynaklı problemlerinin çözülmesi dinleme becerisinin gelişiminde rol oynayabilir. Bu durumun öğretmenler tarafindan fark edilmesi dinleme sürecinin etkili ilerlemesine sebep olabilir. Araştırmada yer alan öğretmenlerin sosyal, psikolojik ve fiziksel ortamın önemini fark ettiği; ancak sosyal ve psikolojik ortamın fiziksel ortam kadar dile getirilmediği görülmektedir. Bu duruma, fiziksel ortama bağl1 problemlerin tespiti ve çözümünün daha hızlı ve kolay olmasının sebep olduğu düşünülmektedir. Sosyal ortam ve psikolojik ortamdan kaynaklı problemler daha uzun ve dikkat gerektiren bir süreci içermektedir.

Psikolojik olarak dinlemeye hazır olmayan bir bireye yapılan hiçbir uygulama başarı vermeyebilir. Aynı şekilde sosyal ortam açısından problem yaşayan öğrencinin başarı durumu olumsuz etkilenebilir. Sınıf içerisinde fiziksel, sosyal ve psikolojik ortamdan kaynaklı problemlerin öğretmenler tarafından fark edilmesinin dinleme becerisinin gelişimine etki edeceği düşünülmektedir.

Araştırma sonucunda fiziksel ortam ile ilgili olarak öncelikle ifade edilen durumun sınıf mevcutları olduğu görülmektedir. Dinleme becerisinin gelişmesinde sınıf mevcutları önemli bir unsurdur. "Dinleme metinleri için dinleme sınıfları oluşturulması (Çaylı, 2012: 128)" dinleme becerisinin gelișimini destekleyebilir. Dinleme derslerinde sınıf mevcutlarının Teknoloji Tasarım derslerine yönelik olan "Dersteki öğrenci sayısı 25'i geçmemelidir. Öğrenci sayısı 25'ten fazla olan sınıflar gruplara ayrılmalıdır (MEB, 2018: 9)" esasına benzer şekilde düzenlenmesi dinlediğini anlama başarısına etki edebilir.

Araştırmaya katılan öğretmenler, dinleme metinlerinin; merak uyandıran, dikkat çeken, seviye uygun, anlaşılabilir, günlük hayatla ilişkili metinler olmasının önemi üzerinde durmaktadır. Ayrıca tür faktörü, metnin uzunluğu, içerik de öğretmenler tarafından göz ardı edilmemektedir. Dinleme becerisinin gelişimini destekleyecek metinlerin; dinlemeye olan ilgiyi arttırması, seviyeye uygun ve kolay anlaşılır olması gerekir. "Dil öğretim sürecinde uygulanan yaklaşım ve yöntemler kadar seçilen metinlere de önem vermeyi gerektirmektedir. Bilindiği gibi dil öğretiminin en önemli ve temel aracı metinlerdir. Metinler öğrencilerin dil, zihinsel ve sosyal becerilerini geliştirmede önemli bir yere sahiptir (Güneş, 2013: 2).” Bu sebeple metin seçiminin dinleme becerisinin gelişimine etkisinin fark edilmesi önemlidir. Öğrencilerin ilgi ve ihtiyaçlarına uygun, öğrencilere dinleme zevki veren metinlerin seçilmesi dinleme becerisine katkı sağlayabilir; öğrencilerin gelişimine, dinleme becerisine karşı tutumuna ve ders başarısına etki edebilir.

Katılımcı ögretmenlerin büyük bir kısmı olay yazılarının dinleme becerisinin gelişiminde etkili olduğunu düşünmektedir. Diakidoy vd. (2005: 69) metin türüne göre; genel olarak, öğrencilerin açıklayıcı metinleri anlama seviyesinin, anlatısal (öyküleyici) metinleri anlama seviyesinden düşük olduğu görmüştür. Ayrıca Yıldırım vd. (2010) beşinci sınıf düzeyinde yaptığ araştırmasında hem okumada hem de dinlemede öyküleyici metnin bilgi verici metinden daha iyi anlaşıldığını belirtmiştir. Katrancı (2012: 59) bilgilendirici metin testlerinde okuduğunu ve dinlediğini anlama arasındaki ilişkinin öyküleyici metinlere göre daha düşük olduğunu ifade etmiştir. Seçilen dinleme metninin türü, öğrencinin dinleme becerisini geliştirmeyi ön planda tutmalıdır. Öğrencilerin kolay anlayacağ 1 , zevk aldığı olay türünde metinlerin kullanımı öncelenmeli; ilerleyen sınıf seviyelerinde kademeli olarak düşünce yazısı türünde metinlere yer verilmelidir.

Öğretmenler dinleme öncesi metne hazırlık uygulamalarında özellikle, öğrencilerin dikkatini çekmeye ve öğrenciyi derse güdülemeye çalışmaktadır. Ders öncesi hazırlıktaki "temel amaç, metin işleme sürecinde öğrencilerin metin aracılığıyla öğrenme etkinliklerine daha etkin katılmalarına hazır hale gelmelerini sağlamaktır (Göçer, 2017: 118)”. Bu amaç doğrultusunda 
öğretmenler tarafından, dinleme metinlerine yönelik yapılan hazırlık uygulamalarına dikkat edilmesi gerekir. Araştırma sonucunda dinleme metninin konusunu öğrencilere önceden veren öğretmen olduğu görülmüştür. Dinleme metninin orijinalliğine zarar verecek hazırlıklarda bulunulmamasının, öğrencinin metin ile ders anında karşılaşmasının, öğrencinin ilgisini kaybetmemesi açısından önemli olduğu düşünülmektedir.

Dinleme öncesi yapılan hazırlık uygulamaları, becerinin gelişiminde önemli rol oynayabilir. Dinleme öncesinde; öğrencinin istekli hale getirilmesi, ilgi ve dikkatin konu üzerine çekilmesi, merak duygusunun uyandırılması, dinleme kurallarının hatırlatılması, dinleme türü hakkında bilgi verilmesi dinlediğini anlama başarısına etki edebilir. Bu sebeple dinleme metnine geçmeden önce öğrencilerin olabildiğince derse hazır hale gelmesi gerekmektedir.

Öğretmenler dinleme sırası uygulamalarında, öğrencilere metne yönelik sorular sormakta ve öğrencinin dikkatini metne çekmeye çalışmaktadır.

Araştırmaya katılan öğretmenler tarafından kullanılan ölçme değerlendirme yöntemleri geleneksel anlayışla sınırlı kalmaktadır. Tamamlayıcı ölçme değerlendirme uygulamaları göz ardı edilmektedir. Öğrencilerin aktif olarak sürece katılımına imkân veren tamamlayıcı ölçme değerlendirme uygulamalarının yaygınlaşması dinleme becerisinin gelişim durumunun değerlendirilmesine katkı sağlayabilir, öğrencinin içselleştirdiği bilgileri göstermesine olanak verebilir. Öğrencinin öğrenmelerinin sonucuna değil sürecine bakılması yapılandırmac1 yaklaşımın ruhuna uygun olacaktır. Bu anlayış için tek başına geleneksel ölçme değerlendirme araçları yeterli olmayabilir. "Öğretme-öğrenme sürecinin değerlendirilmesinde geleneksel ölçme değerlendirme tekniklerinin yanı sıra tamamlayıcı ölçme-değerlendirme tekniklerine de yer verilmesi gerekmektedir. Yapılandırmacı anlayışta öğrenciler kendilerine yöneltilen problemler için çözüm önerilerini, kimi zaman çeşitli sunum tekniklerini kullanarak sözlü bir biçimde, kimi zaman da yaratıcılıklarını kullanarak geliştirdikleri ürünleri sergileme biçiminde ortaya koyarlar (Göçer vd. 2017: 264)".

Öğretmenlerin uygulamalarında dinleme öncesi, dinleme sırası ve dinleme sonrası stratejilerinin bir kısmını kullandıkları görülmüştür. Ancak dinleme stratejilerine yönelik olarak görüşme formlarında yer alan sorulara verilen cevaplardan hareketle, öğretmenlerin stratejiler hakkında yeterli alan bilgisine sahip olmadıkları anlaşılmaktadır. Dinleme stratejilerinin kullanımı dinleme becerisinin gelişiminde önemli rol oynayabilir. "Öğretmen, dinleme etkinliklerinde karşılaşılan problemleri ortadan kaldırma aşamasında dinleme stratejilerinden yararlanabilir (Demir Atalay \& Melanlığlu 2016: 1888)’. Bu sebeple öğretmenlerin süreç içerisinde dinleme stratejilerini kullanmaları, dinleme becerisinin gelişimini destekleyebilir.

Araştırmaya katılan öğretmelerin uygulamalarında; katılımlı, katılımsız ve not alarak dinleme türlerini kullandığı görülmektedir. Öğrencilerin eğitim öğretim süreci içerisinde farklı dinleme stilleri ile karşılaşması önemlidir. "Dinleme stillerinin bilinmesi ve öğrencilere olumlu dinleme stillerini uygulama fırsatı verilmesi dinleme eğitimine katkı sağlayabilir (Epçaçan, 2013: 344)".

Materyal kullanımının dinleme becerisi için önem taşıdığı düşünülmektedir. "Piaget, soyut işlemler döneminin bireyin 11 yaşına girmesiyle başladığını belirtilmektedir (Senemoğlu, 1997)". Soyut işlemler dönemine yeni giren ortaokul öğrencilerinin öğrenmelerini somut materyallerle desteklemek, dinleme metinlerinin anlaşılmasına ve zihinde şekillenmesine katkı sağlayabilir. "Öğrencilere etkili dinleme becerisi kazandırmada bir başka önemli nokta, onlara değerli/faydalı materyaller sunmaktır. İçerik ve etkinlikler, öğrencilerin ilgisini çekecek nitelikte olmalıdır. Ĕger öyle değilse öğrencilerde ya çok az bir gelişme olur ya da hiçbir gelişme olmaz (Kingen, 2000:276; akt. Doğan, 2008: 265)".

Seçilen metinlerin ve yürütülen uygulamaların niteliğinin dinleme becerisinin gelişimine etki ettiği, araştırmaya katılan öğretmenlerce özellikle ifade edilmektedir. Öğrencilerin dinleyerek anladığı metinlerin seçimi, okuma metinlerden farklı olarak ele alınmalıdır. Yaş gurubu dikkate alınarak, öğrencinin dinlemekten hoşlanacağı tür ve nitelikte metinlerin seçimi ile dinlediğini anlama başarısına katkı sağlanabilir. "Dinleme metinleri, kendi içerisinde yapıca ve anlamca bütünlük taşıyan, öğrencinin yaş ve sınıf düzeyi ile ilgi ve ihtiyaçlarına uygun metinler olmalıdır. 
Metinlerde söz konusu niteliklerden birinin yer almaması, diğer öngörülerin de gerçekleşmesini geçersiz hale getirdiği söylenebilir (Gündoğdu, 2011: 1188)".

Araştırmaya katılan öğretmenler dinleme becerisinin geliştirilebilir bir beceri (Aytan, 2011; Çayl1, 2012; Doğan, 2008; Epçaçan, 2013; Melanlıŏlu, 2012; Tabak \& Göçer, 2014) olduğu görüşündedir. Öğretmenlerin dinleme becerisinin gelişimine yönelik olumlu tutumları bu becerinin gelişiminde önemli rol oynayabilir.

\section{ÖNERILER}

Milli Eğitim Bakanlığı tarafından dinleme becerisine yönelik hizmet içi kurslar düzenlenmeli ve öğretmenler bu kurslarla eksik alan bilgilerini tamamlamalıdır.

Dinleme becerisinin gelişimi açısından fiziksel, psikolojik ve sosyal ortamın önemi öğretmenler tarafından göz ardı edilmemelidir.

Seçilen dinleme metinlerinin türü, sınıf seviyesi göz önüne alınarak belirlenmelidir. 5 ve 6 . sınıflarda olay yazılarına ağırlık verilmeli, üst sınıflarda kademeli olarak diğer yazı türlerine geçilmelidir.

Dinleme becerisinin gelişimi için, ortaokul öğrencilerine öncelikle dinleme zevki kazandırılmalıdır. Zaman içerisinde sürece ve dinleme metinlerine alışan öğrencilere, dinlediğini anlama başarısını ön planda tutan dinlemeler yaptırılmalıdır. Bu sebeple kitaplarda yer alan metinlerin içeriği, türü ve etkinlikleri aşamalı olarak ilerletilmelidir.

Metne hazırlık çalışmalarına özen gösterilmelidir. Ders kitapları ve öğretmen uygulamalarında metne hazırlık bölümü ayrıntılı olarak ele alınmalıdır.

Dinleme öncesi yapılan hazırlık çalışmalarında dinleme metninin orijinalliğini kaybetmemesine dikkat edilmelidir.

Öğretmenler uygulamalarında geleneksel ölçme değerlendirme tekniklerinin yanı sıra tamamlayıcı ölçme değerlendirme tekniklerine de yer vermelidir.

Öğrenciler dinleme sürecinde, yapılandırmacı eğitim anlayışına uygun olacak şekilde aktif rol almalıdır.

Öğretmenlerin dinleme stratejilerine yönelik eksik bilgileri tamamlanmalıdır. Dinleme öncesi, dinleme sırası ve dinleme sonrası stratejiler öğretmenler tarafından kullanılmalıdır.

Uygulamalarda dinleme türlerinin çeşitlendirilmesine özen gösterilmelidir. Her öğrencinin farklı özelliklere sahip olduğu göz önüne alınarak, öğrencilerin farklı dinleme türleri ile karşılaşması sağlanmalıdır.

Öğretmenler sorumlu oldukları yaş grubunun özelliklerini dikkate almalı, anlamayı kolaylaştıran uygulamalara başvurmalı ve materyal kullanımına özen göstermelidir. 


\section{KAYNAKÇA}

Akyol, H. (2012). Programa uygun Türkçe öğretim yöntemleri (5. Baskl). Ankara: Pegem Akademi.

Aytan, T. (2011). Aktif öğrenme tekniklerinin dinleme becerisi üzerindeki etkileri. Selçuk Üniversitesi Eğitim Bilimleri Enstitüsü (Doktora Tezi), Konya.

Çaylı, C. \& Göçer, A. (2016). Ortaokul Türkçe derslerinde işlenilen müstakil dinleme metinlerine yönelik öğretmen uygulamalarının değerlendirilmesi. Ahi Evran Üniversitesi Kırşehir Eğitim Fakültesi Dergisi (KEFAD), 17(3), 517-535.

Çaylı, C. (2012). Illköğretim ikinci kademe Türkçe dersi öğretmen kllavuz kitaplarındaki dinleme metinlerine yönelik öğretmen uygulamalarının değerlendirilmesi. Erciyes Üniversitesi Eğitim Bilimleri Enstitüsü, Yayımlanmamış Yüksek Lisans Tezi, Kayseri

Demir Atalay, T. \& Melanlıoğlu, D. (2016). “Ortaokul öğrencileri için dinleme stratejileri ölçeği”nin geçerlilik ve güvenilirlik çalışması. A. Ü. Türkiyat Araştırmaları Enstitüsü Dergisi [TAED] 57, 1885-1904

Demirel, Ö. (1999). Illköğretim okullarında Türkçe öğretimi. İstanbul: MEB Yayınları.

Diakidoy, I. A.; N., Stylianou, P.; Karefillidou, C. \& Papageorg1ou, P. (2005) The relationship between listening and reading comprehension of different types of text at increasing grade levels. Reading Pyschology, 26(1), 55-80.

Doğan, Y. (2007). Illköğretim ikinci kademede dil becerisi olarak dinlemeyi geliştirme çalışmalarl. (Yayımlanmamış Doktora Tezi). Gazi Üniversitesi, Eğitim Bilimleri Enstitüsü. Ankara.

Doğan, Y. (2008). İlköğretim yedinci sınıf öğrencilerinin dinleme becerisini geliştirmede etkinlik temelli çalışmaların etkililiği. Türk Eğitim Bilimleri Dergisi, 6(2), 261-286.

Epçaçan, C. (2013). Temel bir dil becerisi olarak dinleme ve dinleme eğitimi. Adlyaman Üniversitesi Sosyal Bilimler Enstitüsü Dergisi, 6(11), 331-352.

Göçer, A. (2017). Öğrenci merkezli-etkileşimli- metin işleme ve çözümleme süreçli Türkçe özel ögretim yöntemleri (Genişletilmiş 2. Bask1). Ankara: Pegem Akademi.

Göçer, A.; Çavuş, S. \& Çaylı, C. (2017). Türkçe eğitiminde öğrenci gelişim durumunun belirlenmesinde süreç temelli tamamlayıcı ölçme değerlendirme yöntem ve araçları. Süleyman Demirel Üniversitesi Sosyal Bilimler Enstitüsü Dergisi, 3(28), 263-292.

Gündoğdu, A. E. (2011). İlköğretim sekizinci sınıf dinleme metinlerinin çeşitli değişkenler açisından incelenmesi. Turkish Studies, 6(1), 1217-1227.

Güneş, F. (2013). Türkçe öğretiminde metin seçimi. Ana Dili Eğitimi Dergisi, 1(1), 1-12.

Gürel, E. \& Tat, M. (2012). Bir iletişim edimi olarak dinleme ve Türkçede bulunan dinleme temalı atasözleri ile deyimler üzerine bir içerik analizi, Uluslararası Sosyal Araştırmalar Dergisi, 277. 
Katranc1, M. (2012). Üstbiliş stratejileri öğretiminin dinlediğini anlama becerisine ve dinlemeye yönelik tutuma etkisi. (Yayımlanmamış Doktora Tezi). Hacettepe Üniversitesi, Sosyal Bilimler Enstitüsü. Ankara.

Kuşçu, H. (2010). İlköğretim ikinci kademe öğrencilerinin dinleme, konuşma, okuma ve yazılı anlatım becerilerinin yapılandırıcı yaklaşıma göre geliştirilmesinde Türkçe ögrretmeninin rolü (yayımlanmamış yüksek lisans tezi). İstanbul: Yeditepe Üniversitesi Sosyal Bilimler Enstitüsü.

Maden, S. \& Durukan, E. (2011). Türkçe öğretmeni adaylarının dinleme stillerinin çeşitli değişkenler açısından değerlendirilmesi. Mehmet Akif Ersoy Üniversitesi Sosyal Bilimler Enstitüsü Dergisi, 3(4), 101-112.

MEB (2006). İlköğretim Türkçe dersi öğretim programı ve kılavuzu (6, 7 ve 8. sinıflar). Ankara: Devlet Kitapları Müdürlüğü

MEB (2017). $\quad$ http://www.meb.gov.tr/2016-2017-egitim-ve-ogretim-donemi-istatistikleriyayimlandi/haber/14443/tr (Erişim Tarihi: 03.06.2018)

MEB (2018). Teknoloji ve tasarım dersi ögretim programı (ortaokul 7 ve 8. sinıflar). Ankara: Devlet Kitapları Müdürlüğü.

Melanlığlu, D. (2012). Dinleme becerisinin geliştirilmesinde ailenin rolü. Sosyal Politika Çalışmaları, 7(29), 65-77

Senemoğu, N. (1997). Gelişim öğrenme ve öğretim kuramdan uygulamaya. Ankara: Ertem Yayınc1lik.

Tabak, G. \& Göçer, A. (2014). Dinleme becerisinin geliştirilmesinde parçadan bütüne ve bütünden parçaya işlemler. International Journal of Language Academy, 2(1), 127-135.

Taşer, S. (2012). Konuşma ĕ̌itimi. İstanbul: Pegasus Yayınevi.

Ungan, S. (2009). Dinleme eğitimi. Ahmet Kırkkılıç, Hayati Akyol (Ed.), İlköğretimde Türkçe ögretimi-2.baskı içinde (s. 135-160). Ankara: Pegem A Yayıncılık.

Yıldırım, A. \& Şimşek, H. (2008). Sosyal bilimlerde nitel araştırma yöntemleri (7. baskl). Ankara: Seçkin Yayınları.

Yıldırım, K.; Yıldız, M.; Ateş, S. \& Rasinski, T. (2010). İlköğretim beşinci sınıf Türk öğrencilerin metin türlerine göre okuduğunu ve dinlediğini anlama düzeyleri. Kuram ve Uygulamada Ĕ̈itim Bilimleri, 10(3), 18551891. 